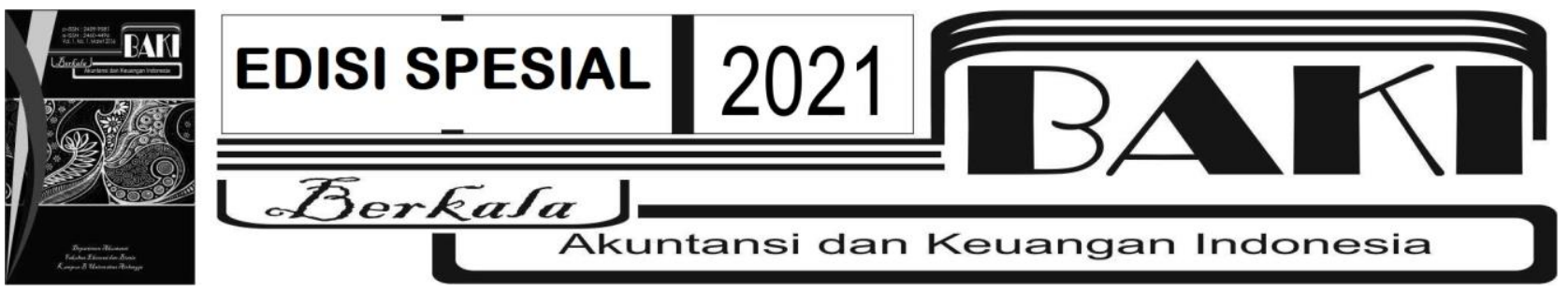

\title{
BASAMO SAMARINDA'S HERBAL AND HERBAL HEALTH BUSINESS IN THE MIDST OF THE PANDEMIC COVID-19
}

\section{USAHA HERBAL DAN JAMU SEHAT BASAMO SAMARINDA DI TENGAH BADAI PANDEMI COVID-19}

\author{
Ilham Abu ${ }^{1}$, Muhammad Sultan ${ }^{1 *}$ (D) Emil Reza Putra ${ }^{2}$ \\ ${ }^{1}$ Universitas Mulawarman, ${ }^{2}$ Politeknik Pertanian Negeri Samarinda
}

“corresponding author : muhammadsultan812@gmail.com

\section{NFO ARTIKEL}

Histori Artikel:

Tanggal Masuk 10 April 2021

Revisi Diterima 17 Mei 2021

Tanggal Diterima 14 Juli 2021

Tersedia Online 31 Juli 2021

\section{Keyword:}

Business Continuity, Covid-19

Pandemic, Herbs and Herbs
A B STRACK

The Covid-19 pandemic has had a broad impact on all sectors of life in Indonesia, including the economic sector. Not a few business sectors are experiencing losses and even bankruptcy. Therefore, business actors must be able to implement and develop certain strategies in order to survive and gain profits both in the midst of the pandemic storm and after the Covid-19 pandemic. This study aims to obtain information about the strategies of Herbal and Herbal Medicine business players in Sehat Basamo in the midst of the Covid-19 pandemic. This study uses a qualitative design with a case study approach. Research informants are sellers of herbs and herbal medicine Sehat Basamo as many as 4 people who were selected by purposive sampling. In addition, 4 informants were selected who are loyal customers at the Sehat Basamo outlet. The research was carried out in March-April 2021 at four locations of Sehat Basamo outlets in Samarinda City. The data and information obtained were then analyzed qualitatively. The results of the study obtained information that all Healthy Basamo herbal and herbal outlets and customers who visited Sehat Basamo outlets complied with the Covid-19 health protocol according to the government's appeal in controlling the spread of the Covid-19 rate. In addition to complying with health protocols, the Herbal and herbal medicine business of Sehat Basamo has also been proven to be able to survive in the midst of a pandemic and even continue to benefit from the sales of its products. The success of the owner of the Healthy Basamo herbal and herbal outlet in maintaining business continuity and still making profits in the midst of the Covid-19 pandemic by implementing a strategy that is consistent attitude in product presentation, not increasing product prices, friendliness and courtesy of sellers and ensuring the availability of product 
supply. Sales of herbal and herbal products from Sehat Basamo are carried out face-to-face with buyers and the financial accounting management is still manual. Therefore, sellers of Herbal and Jamu Sehat Basamo can take advantage of currently available technology and information both to increase product sales results and in managing digital-based business financial accounting (digital accounting) which is available in various application software.

INFO ARTIKEL

Kata Kunci:

Herbal dan Jamu, Keberlangsungan Usaha, Pandemi Covid-19

\section{A B S T R A K}

Pandemi Covid-19 berdampak luas terhadap sektor kehidupan di Indonesia, termasuk sektor perekonomian. Tidak sedikit sektor usaha yang mengalami kerugian dan bahkan kebangkrutan. Oleh karena itu, pelaku usaha harus mampu menerapkan dan mengembangkan strategi tertentu agar tetap bertahan dan memperoleh keuntungan baik di tengah badai pandemi maupun pasca pandemi Covid-19. Penelitian ini bertujuan untuk memperoleh informasi mengenai strategi pelaku usaha herbal dan jamu Sehat Basamo di tengah pandemi Covid-19. Penelitian ini menggunakan desain kualitatif dengan pendekatan studi kasus. Informan penelitian adalah penjual herbal dan jamu Sehat Basamo sebanyak 4 orang yang dipilih secara purposive sampling. Selain itu, dipilih 4 informan yang merupakan pelanggan setia di outlet Sehat Basamo. Penelitian dilaksanakan bulan Maret-April 2021 di empat lokasi outlet Sehat Basamo di Kota Samarinda. Data dan informasi yang berhasil diperoleh selanjutnya dianalisis secara kualitatif. Hasil penelitian diperoleh informasi bahwa semua outlet herbal dan jamu Sehat Basamo serta pelanggan yang berkunjung ke outlet Sehat Basamo mematuhi protokol kesehatan Covid-19 sesuai himbauan pemerintah dalam mengendalikan penyebaran laju Covid-19. Selain kepatuhan dalam mengikuti protokol kesehatan, usaha herbal dan jamu Sehat Basamo juga terbukti mampu bertahan di tengah pandemi dan bahkan tetap memperoleh keuntungan dari hasil penjualan produknya. Keberhasilan pemilik outlet herbal dan jamu Sehat Basamo dalam menjaga keberlangsungan usahanya dan masih tetap memperoleh keuntungan di tengah pandemi Covid-19 dengan menerapkan strategi yakni sikap konsisten dalam penyajian produk, tidak menaikkan harga produk, keramahan dan kesopanan penjual serta menjamin ketersediaan pasokan produk. Penjualan produk usaha herbal dan jamu Sehat Basamo dilakukan secara tatap muka langsung dengan pembeli dan pengelolaan akuntansi keuangannya juga masih secara manual. Oleh karena itu, penjual herbal dan jamu Sehat Basamo dapat memanfaatkan teknologi dan informasi yang tersedia saat ini baik untuk meningkatkan hasil penjualan produk maupun dalam pengelolaan akuntansi keuangan usaha yang berbasis digital (digital accounting) yang telah tersedia dalam berbagai software aplikasi.

Berkala Akuntansi dan Keuangan Indonesia p-ISSN: 2459-9581; e-ISSN 2460-4496 DOI: 10.20473/baki.v6ix.26318

Open access under Creative Common Attribution-Non Commercial-Share A like 4.0 International Licence (CC-BY-NC-SA) @(1) $\Theta($ ) 


\section{Pendahuluan}

Pandemi Covid-19 masih berlangsung hingga saat ini telah menimbulkan begitu banyak permasalahan khususnya di sektor perekonomian secara global dan di Indonesia. Usaha Mikro, Kecil, dan Menengah (UMKM) merupakan salah satu sektor bisnis yang banyak digeluti masyarakat Indonesia pun tidak luput dari adanya Covid-19. Hal ini dibuktikan banyaknya UMKM yang mengalami penurunan omzet secara signifikan sejak adanya pandemi Covid-19 (Amri, 2020).

Kehadiran UMKM biasanya berada di barisan terdepan yang mampu bertahan saat kondisi perekonomian Indonesia mengalami keterpurukan, akan tetapi pandemi Covid-19 justru mengalami guncangan ekonomi yang begitu hebatnya sehingga banyak UMKM yang menghentikan aktivitas ekonominya secara tiba-tiba akibat penurunan permintaan dan terganggunya rantai pasokan bisnis UMKM (Thaha, 2020). Tidak terkecuali investor yang berencana menanamkan modalnya pada berbagai bisnis (Sumarni, 2020) pun menjadi terhambat akibat Covid-19.

Usaha herbal dan jamu yang merupakan salah satu bisnis UMKM di bidang industri minuman pun ikut merasakan begitu besarnya dampak buruk Covid-19. Tidak sedikit pelaku industri makanan dan minuman menutup usahanya karena penurunan pendapatan yang berakibat pada pengurangan karyawan. Selain itu, terjadinya perubahan perilaku konsumen dalam mengkonsumsi makanan dan minuman dengan memilih makanan yang sehat, higienis, aman bagi tubuh dan dalam pembeliannya menggunakan jasa delivery (Prakoso, 2020).

Berbagai strategi dan dukungan pemerintah dalam menyelamatkan UMKM dari kepungan dampak Covid-19 melalui strategi jangka pendek dan strategi jangka panjang untuk menjaga kesinambungan UMKM (Sugiri, 2020). Pelaku usaha UMKM mengubah strategi penjualan melalui skema digitalisasi dapat menjadi salah satu alternatif menyelamatkan dan sekaligus pengembangan kewirausahaan digital di Indonesia pada masa pandemi Covid-19 (Arianto, 2020). Pemanfaatan digitalisasi melalui media sosial memberikan prospek yang baik karena memudahkan proses pemesanan dan pembelian sehingga dapat mempengaruhi peningkatan angka penjualan produk UMKM (Abidin et al., 2020).

Kebutuhan makanan dan minuman sehat selama pandemi Covid-19 menjadi buruan kalangan masyarakat tertentu. Mereka meyakini bahwa minuman penambah stamina seperti herbal dan jamu saat pandemi dapat meningkatkan kekebalan tubuh sehingga tidak mudah mengalami kelelahan yang berujung mudahnya terinfeksi virus tertentu seperi virus Covid-19. Kalangan masyarakat pekerja fisik berusia lanjut misalnya lebih banyak mengkonsumsi minuman herbal dan jamu karena mudahnya merasakan kelelahan setelah bekerja seharian.

Kemampuan pelaku usaha dalam melakukan segmentasi pasar produk secara detail dapat mempengaruhi pemilihan manajemen strategi pemasaran produk secara tepat. Strategi 
pemasaran suatu produk usaha perlu mempertimbangkan kesesuaian karakteristik konsumennya (Priangani, 2013). Sebagai contoh, usaha makanan dan minuman kekinian yang banyak digemari generasi milenial mungkin sesuai dengan teknik pemasaran menggunakan perangkat teknologi delivery tetapi pada segmentasi konsumen berbeda pun dibutuhkan strategi yang berbeda pula. Minuman herbal dan jamu lebih banyak dikonsumsi oleh kalangan pekerja fisik berusia lanjut dengan melakukan pembelian langsung di outlet-outlet dekat tempat tinggalnya.

Pelaku usaha herbal dan jamu memiliki kemampuan manajemen bisnis yang berbedabeda. Pandemi Covid-19 yang belum diketahui secara pasti kapan berhentinya dan hilang dari Indonesia menuntut kecakapan tersendiri dan diyakini pelaku usaha jamu dan herbal sebagai suatu strategi bertahan dan tetap meraup keuntungan di tengah pandemi. Maraknya usaha yang mengalami kegagalan di tengah badai pandemi Covid-19 dapat dijadikan sinyal adanya keterbatasan bahkan ketidakmampuan pelaku usaha dalam menjalankan usahanya.

Penjual herbal dan jamu yang tergabung dalam usaha keluarga Sehat Basamo di Kota Samarinda pun tidak terhindarkan dari dampak adanya pandemi Covid-19. Usaha herbal dan jamu Sehat Basamo telah beroperasi sejak tahun 2012 hingga saat ini. Berdasarkan permasalahan tersebut, diperlukan suatu kajian mendalam terhadap penjual herbal dan jamu Sehat Basamo yang mampu bertahan dan bahkan meraup keuntungan di tengah badai pandemi Covid-19. Data dan informasi yang diperoleh nantinya dapat menjadi alternatif solusi dan motivasi bagi sektor usaha serupa dan sektor usaha lainnya agar mampu mempertahankan usaha baik di tengah pandemi maupun pasca pandemi Covid-19.

\section{Tinjauan Pustaka}

Berbagai jenis usaha terutama pelaku UMKM pada masa pandemi Covid-19 yang masih berlangsung hingga kini melakukan berbagai cara dan inovasi agar usaha mereka mampu bertahan dan bahkan dapat memperoleh keuntungan. Akan tetapi, tidak sedikit juga UMKM yang justru harus mengalami kerugian hingga berujung pada pengurangan dan bahkan pemberhentian karyawan sekitar 6,4 juta orang (Alfin, 2021).

Pemerintah Indonesia mengeluarkan kebijakan dan mengimbau kepada masyarakat untuk menerapkan protokol kesehatan meliputi menjaga jarak fisik, mencuci tangan menggunakan sabu atau cairan pembersih tangan (hand sanitizer), dan memakai masker (Kemenkes RI, 2020). Kebijakan tersebut ditindaklanjuti oleh pemerintah daerah termasuk Provinsi Kalimantan Timur yang mengatur tentang pencegahan penyebaran Covid-19 (Kalimantan Timur, 2020). Begitu pula Pemerintah Kota Samarinda mengambil kebijakan tentang penegakan protokol kesehatan khusunya pada para pelaku usaha (Samarinda, 2021). 
Pemerintah Indonesia tidak tinggal diam melihat persoalan yang dihadapi para pelaku ekonomi khususnya pelaku UMKM. Salah satu kebijakan pemerintah adalah pemberian bantuan sosial, insentif pajak, dan perluasan modal kerja terhadap pengembangan UMKM di masa pandemi Covid-19. Kebijakan pemerintah tersebut berpengaruh terhadap perkembangan UMKM di masa pandemi Covid-19 (Natasya \& Hardiningsih, 2021).

Keterlibatan dan partisipasi berbagai pihak seperti pemerintah, swasta, penyedia jasa keuangan, para pelaku usaha, dan pihak lainnya harus saling bahu-membahu agar sektor usaha tetap bertahan di tengah pandemi Covid-19. Berikut akan diuraikan beberapa hasil penelitian yang telah dilakukan tentang strategi berbagai jenis usaha yang dilakukan agar tetap bertahan di masa pandemi Covid-19.

Industri makanan dan minuman melakukan strategi dalam memasarkan hasil produksinya melalui media sosial. Namun demikian, strategi ini membutuhkan dana tambahan dan tentunya memberikan dampak pada berkurangnya modal usaha (Rosmadi, 2021). Strategi pemasaran melalui media sosial juga dilakukan pada usaha minuman Kamsia Boba di Kabupaten Bangkalan dengan memberikan pengantaran gratis setiap pembelian minimal 3 produk. Langkah tersebut dinilai terbukti sudah tepat dan efektif mempertahankan keberlangsungan usahanya dan omset seperti biasanya (Syaiful, 2020).

Strategi melalui perdagangan secara e-commerce dengan melakukan pemasaran secara digital, perbaikan kualitas produk, dan penambahan layanan serta menjalin dan mengoptimalkan hubungan pemasaran pelanggan juga terbukti efektif dalam mempertahankan usaha UMKM (Hardilawati, 2020). Begitu pula implementasi e-marketing melalui marketplace yang dilakukan oleh para pengusaha UMKM di tengah Pandemi Covid-19 agar kegiatan usahanya tetap berjalan dan menghasilkan nilai ekonomi (Awali, 2020).

Era teknologi informasi banyak dimanfaatkan oleh pelaku usaha saat ini. Selain pemanfaatan media sosial dan berbagai platform pemasaran digital, pembuatan website juga mampu mengatasi kesulitan pemasaran produk usaha di era revolusi industri 4.0 dan masa pandemic Covid-19 (Yasir et al., 2020). Strategi lainnya adalah penerapan program afiliasi berbasis virtual team dan hasilnya dinilai berdampak cukup baik kepada perekonomian Negara maupun kehidupan para pelaku UMKM serta pengurangan tingkat pengangguran di tengah pandemi Covid-19 dengan tetap menerapkan Work From Home (Shofiana, 2020).

Selain pemanfaatan teknologi dan media informasi yang banyak dilakukan pelaku usaha beberapa tahun terakhir dan pada masa pandemi Covid-19 ini, pelaku usaha juga perlu meningkatkan kemampuan dalam menilai karakteristik wirausaha yang sesuai dengan bakat, lingkungan eksternal dan strategi bertahan UMKM dalam menjaga keberlangsungan usaha karena karakteristik wirausaha merupakan variabel yang dominan mempengaruhi keberlangsungan usaha (Dwiastanti, Anis, Mustapa, 2020). Hal yang tidak kalah pentingnya 
yang perlu dimiliki oleh seorang pengusaha di masa pandemi Covid-19 adalah daya juang (adversity quotient), motivasi dengan target pencapaian yang terukur, spirit kerja yang tinggi serta keyakinan melalui pertimbangan dan perencanaan yang matang (Soetjipto, 2020).

Salah satu jenis produk yang banyak digemari oleh masyarakat saat pandemi Covid-19 melanda adalah minuman herbal dan jamu. Meminum herbal dan jamu merupakan salah satu cara yang diyakini masyarakat mampu menghadapi serangan infeksi Covid-19 karena mengoptimalkan sistem imun tubuh sehingga membantu mencegah dan menunjang proses penyembuhan (Khusnul Zauhani, 2020). Meminum jamu juga diyakini sebagian masyarakat Indonesia mampu menjaga daya tahan tubuh (Ingsih et al., 2020) dan sebagai alternatif untuk mencegah infeksi dari virus Covid-19 sehingga keberadaan jamu tradisional dan budaya konsumsi jamu kembali menjadi tren ditengah-tengah masyarakat (Sutana, 2020).

Pemerintah juga menganjurkan kepada masyarakat selalu menjaga kesehatan diri dengan selalu menjaga pola makan yang bergizi serta memberi asupan vitamin untuk menjaga imunitas tubuh tetap terjaga. Indonesia kaya akan tanaman sebagai rempah alami dan terbukti memberikan manfaat seperti mampu meningkatkan daya tahan tubuh, mengobati radang, mengurangi rasa mual, mengatasi perut yang kembung, mengurangi nyeri saat haid, obat alergi, menangkal bakteri jahat, penawar racun, mengobati maag, menstabilkan kadar gula darah, meredakan peradangan usus, melawan infeksi, membantu menurunkan berat badan merawat hati dan masih banyak manfaat lainnya (Azizuddin, 2021).

Selain meningkatkan daya tahan tubuh di masa pandemi Covid-19, jamu herbal juga dapat dijadikan sebagai peluang bisnis (Drajat AR, 2020). Anjuran pemerintah mengenai pemanfaatan produk herbal di masa pandemi Covid-19 untuk menjaga stamina tubuh semakin mendorong keinginan masyarakat untuk memilih mengkonsumsi produk herbal dan jamu dengan berbagai alasan seperti khasiat, kemudahan memperoleh, kedekatan dengan penjual, dan konsep back to nature (Dewati \& Saputro, 2020).

Pelaku usaha herbal dan jamu juga telah banyak menerapkan strategi pemasaran produknya kepada konsumen melalui pemanfaatan teknologi dan informasi. Pemasaran produk jamu akan lebih masif melalui digital marketing (Putra RP, 2020). Promosi melalui media sosial dan variasi produk berpengaruh positif dan signifikan terhadap keputusan pembelian konsumen jamu (Andriani, 2021).

Berbagai hasil penelitian yang telah diuraikan sebelumnya diperoleh informasi bahwa keberlangsungan suatu usaha di masa pandemi Covid-19 sangat ditentukan strategi pemasaran produk yang dimiliki. Begitu pula keberlangsungan sejumlah pelaku usaha herbal dan jamu yang memaksimalkan pemanfaatan teknologi informasi saat ini sehingga mampu bertahan di tengah pandemi Covid-19. Ternyata strategi yang dijalankan oleh penjual herbal dan jamu yang tergabung dalam Sehat Basamo di Kota Samarinda belum memilih strategi 
pemasaran digitalisasi dan kenyataannya mampu bertahan pada situasi sulit seperti saat pandemi Covid-19.

Penelitian sebelumnya juga lebih banyak mengulas keberlangsungan usaha di tengah pandemi Covid-19 dari aspek pemasaran produk usahanya, tetapi masih terbatas informasi mengenai kepatuhan pelaku usaha dan pengunjungnya dalam menerapkan protokol kesehatan saat melakukan kegiatan usahanya di tengah pandemi Covid-19. Selain itu, subjek penelitian sebelumnya lebih fokus pada pemilik usaha di tengah pandemi dan masih kurang informasi dari pengunjung atau pembeli mengenai alasan mereka berbelanja rutin di tempat tersebut.

Berdasarkan hal tersebut, penelitian ini selain mengkaji secara mendalam strategi keberlangsungan usaha herbal dan jamu Sehat Basamo juga akan menelaah informasi kepatuhan pelaku usaha dan konsumen saat bertransaksi langsung di tengah pandemi Covid19 serta alasan konsumen membeli herbal dan jamu di outlet Sehat Basamo. Informasi dari konsumen herbal dan jamu akan membantu peneliti mengungkap dan mendalami strategi yang dilakukan outlet herbal dan jamu Sehat Basamo sehingga konsumennya rutin dan setia hingga saat ini.

\section{Metodologi Penelitian}

Jenis penelitian yang dipilih adalah kualitatif dengan pendekatan studi kasus (Kusmarni, 1989). Informan pada penelitian ini adalah penjual jamu di setiap outlet Sehat Basamo sebanyak 5 informan. Setiap informan adalah pemilik langsung outlet tetapi berada di bawah naungan usaha keluarga yg dinamakan Sehat Basamo. Informan dipilih secara purposive sampling dengan kriteria informan yang memiliki outlet telah beroperasi sebelum pandemi Covid-19, bersedia diwawancarai, dan mampu berkomunikasi. Pengumpulan data dan informasi dilakukan dengan wawancara langsung menggunakan instrumen pedoman wawancara, dokumentasi dan rekaman arsip berupa buku harian penjualan, dan observasi langsung ke setiap outlet herbal dan jamu Sehat Basamo. Terdapat 3 informan pemilik outlet jamu Sehat Basamo yang beroperasi sekitar pukul 17.00-24.00 WITA dan 1 outlet pukul 09.0024.00 WITA sehingga pengumpulan data dan informasi disesuaikan dengan jam operasional outlet dan kesediaan informan di sela-sela waktu kesibukan melayani pelanggan. Selain informan tersebut, peneliti juga memilih 4 orang pelanggan outlet yang rutin (minimal 2 kali seminggu) meminum herbal dan jamu sebagai sumber infomasi tambahan untuk mengungkap alasan mereka menjadi pelanggan setia di outlet Sehat Basamo. Informasi yang berhasil diperoleh selanjutnya dianalisis secara kualitatif (Hariyanti, 2015). Penelitian dilakukan bulan Maret hingga awal April 2021 pada 4 outlet herbal dan jamu Sehat Basamo di Kota Samarinda. 


\section{Analisis dan Pembahasan}

Pelaksanaan pengumpulan data dan informasi berlangsung masih dalam situasi pandemi Covid-19 sehingga peneliti dan informan senantiasa menerapkan protokol kesehatan yaitu menjaga jarak, mencuci tangan dan hand sanitizer, dan memakai masker. Waktu penelitian dilakukan sekitar sebulan karena peneliti harus menyesuaikan waktu pemilik outlet herbal dan jamu untuk dilakukan proses wawancara dan pengamatan langsung selama penelitian.

Informan (penjual) pada penelitian ini semuanya berjenis kelamin laki-laki. Umur informan antara 22-32 tahun. Pendidikan terakhir informan adalah SMA/sederajat. Lokasi outlet herbal dan jamu tersebar pada empat jalan utama di Kota Samarinda dengan lama usaha yang mereka geluti berkisar 5-10 tahun.

Tabel 4.1. Karakteristik Informan Penelitian (Penjual)

\begin{tabular}{c|c|c|c|c}
\hline \multicolumn{1}{c}{ Umur } & Jenis kelamin & Pendidikan & Lokasi & Lama Usaha \\
32 tahun & Lk & SMA & Jl. Pandjaitan & 7 tahun \\
\hline 30 tahun & Lk & SMA & Jl. Cendana & 10 tahun \\
\hline 22 tahun & Lk & SMA & Jl. KS. Tubun & 5 tahun \\
\hline 27 tahun & Lk & SMA & Jl. M. Said & 6 tahun \\
\hline
\end{tabular}

Sumber: Data Primer, 2021

Sedangkan informan (pembeli) di outlet herbal dan jamu Sehat Basamo Samarinda berumur antara 32-52 tahun. Pendidikan terakhir pembeli adalah SMP dan SMA/sederajat. Mereka telah berlangganan di outlet Sehat Basamo antara 3-10 tahun.

Tabel 4.2. Karakteristik Informan Penelitian (Pembeli/Pelanggan)

\begin{tabular}{|c|c|c|c|c|}
\hline Umur & Jenis kelamin & Pendidikan & Lokasi & Lama Langganan \\
\hline 32 tahun & $\mathrm{Pr}$ & SMA & Jl. Pandjaitan & 3 tahun \\
\hline 33 tahun & Lk & SMA & Jl. Cendana & 5 tahun \\
\hline 35 tahun & Lk & SMA & Jl. KS. Tubun & 4 tahun \\
\hline 52 tahun & Lk & SMP & Jl. M. Said & 10 tahun \\
\hline
\end{tabular}

Sumber: Data Primer, 2021

\subsection{Kepatuhan Outlet Herbal dan Jamu SB dan Pengunjungnya Terhadap Protokol Kesehatan} Covid-19

Sejak Pemerintah Indonesia menghimbau dan menetapkan kebijakan Pembatasan Sosial Berskala Besar (PSBB) (BNPB, 2020) sebagai salah satu upaya mengendalikan laju Covid-19 di tanah air, sebagian pelaku usaha merasakan kegelisahan akan nasib usahanya. Bahkan, tidak sedikit usaha yang tidak dapat tertolong lagi akibat munculnya pembatasan tersebut. Penjual herbal dan jamu SB pun mengikuti kebijakan tersebut sebagai wujud kepatuhan mereka terhadap kebijakan pemerintah dan kepeduliannya dalam meminimalkan penyebaran Covid-19. Informasi tersebut diungkapkan informan pada hasil kutipan wawancara berikut : 
“.....kita harus patuhi protokol kesehatan yang dibuat pemerintah meskipun sebenarnya pasti berpengaruh ke penghasilan....., sudah disediakan cairan pembersih tangan bagi pelanggan" (Iv, 27 tahun)

“.....kursi pembeli yang minum di sini juga sudah diatur jaraknya agar tidak berdekatan saat ramai....." (Ik, 30 tahun)

“.....sebenarnya ada juga kita siapkan masker bagi pembeli yang tidak pakai masker, di awal Covid itu karena susahnya masker jadinya berbayar tapi harganya normal" (An, 32 tahun)

Praktik penerapan protokol kesehatan Covid-19 yang dilakukan di outlet Sehat Basamo sejak adanya himbauan pemerintah masih berlangsung hingga penelitian ini dilakukan. Informan pada semua outlet Sehat Basamo memakai masker saat melakukan transaksi dengan pengunjung. Selain itu juga dilakukan pengaturan jarak kursi dan hand sanitizer masih tetap disediakan secara gratis bagi pengunjung outlet herbal dan jamu Sehat Basamo.

Partisipasi pelaku usaha dalam membantu mengendalikan Covid-19 di tanah air dapat diwujudkan melalui kepatuhan mereka menerapkan protokol kesehatan saat operasional usahanya. Selain itu, keberadaan outlet penjualan produk dapat menjadi salah satu tempat yang berpotensi menimbulkan kerumunan orang sehingga diperlukan komitmen pelaku usaha dalam memberikan pelayanan terbaiknya seperti menyediakan berbagai fasilitas pendukung penerapan protokol kesehatan di tempat usahanya (Rini Eka Sari, Novi Yanita, 2020).

Selain komitmen pelaku usaha dalam menerapkan protokol kesehatan, juga diperlukan sikap kepatuhan para pengunjung yang datang meminum herbal dan jamu. Sikap pengunjung outlet herbal dan jamu Sehat Basamo yang datang berbelanja pun terlihat patuh dalam menjalankan protokol kesehatan dibuktikan dengan pemakaian masker, memanfaatkan hand sanitizer yang disediakan di outlet Sehat Basamo, dan menjaga jarak duduk saat meminum jamu di outllet Sehat Basamo. Pengunjung outlet herbal dan jamu Sehat Basamo mengatakan bahwa pandemi Covid-19 merupakan masalah bersama dan diperlukan kebersamaan dan kesadaran semua warga dalam mengatasinya. Ungkapan tersebut dapat dilihat pada hasil kutipan wawancara berikut :

“.....Corona ini kan musuh kita bersama sehingga tidak bisa ditangani kalau kita sebagai masyarakat juga tidak ikut membantu pemerintah....." (Su, 52 tahun)

".....di sini juga telah tersedia cairan untuk membersihkan tangan jadi bisa digunakan.....kursinya juga rapi berjarak" (Od, 32 tahun)

".....masker juga ada tapi kalau bisa gratis lah haha.....kalau saya lihat di sini sudah sesuai protokol Covid jadi aman saja untuk minum jamu...." (Em, 35 tahun)

Hadirnya kedisiplinan dan kepatuhan (Jati, 2020) yang dipraktikkan oleh pemilik usaha herbal dan jamu Sehat Basamo dan juga pengunjungnya saat bertransaksi merupakan hal 
positif dalam mendukung upaya pemerintah untuk mengendalikan penyebaran Covid-19 di Indonesia (Agustino, 2020). Komitmen pemilik usaha herbal dan jamu Sehat Basamo dalam menerapkan protokol kesehatan Covid-19 menunjukkan bahwa mereka bukan hanya memikirkan keuntungan saja di tengah pandemi tetapi juga memberikan contoh praktik yang cukup baik untuk dipraktikkan oleh pemilik usaha di tempat lainnya di Indonesia.

\subsection{Keberlangsungan dan Strategi Usaha Herbal dan Jamu Sehat Basamo di Masa Pandemi Covid-19}

Pemilik usaha herbal dan jamu juga merasakan secara langsung dampak adanya pandemi Covid-19 terutama di awal kemunculannya. Informan mengatakan bahwa pada awal munculnya Covid-19 pelanggan setianya pun bahkan tidak datang membeli. Kurang lebih sebulan awal pandemi Covid-19, penghasilan informan mengalami penurunan dari rata-rata penghasilan sebelum Covid-19. Akan tetapi, terdapat 1 outlet herbal dan jamu Sehat Basamo yang justru di awal pandemi memperoleh penghasilan melebihi rata-rata sebelum pandemi. Pernyataan informan tersebut dapat dilihat pada kutipan hasil wawancara berikut :

“.....Desember 2019 masih stabil 800 ribu-1 juta per hari.....setelah ramai berita sekitar April 2020 turun menjadi 500-600 ribu per hari.....saat ini kembali di angka 1 juta per hari" (An, 32 tahun)

“.....sekitar sebulanan Covid, penghasilan menurun karena pengunjung yang biasanya beli saja tidak datang belanja.....sebelumnya biasa 700-800 ribu per hari tetapi saat awal Covid hanya 300-400 ribu.....Sekitar pertengahan bulan ke-2 Covid sampai saat ini kembali di kisaran 700-800 ribu per harinya tetapi masih turun-naik" (Iv, 27 tahun)

“.....biasanya di angka 1-1,3 juta per hari.....awal Covid turun jadi 1 jutaan bahkan tidak cukup sejuta.....Saat ini sekitaran sejutaan lagi.....(Vi, 22 tahun)

“.....sebelum pandemi 1,6-1,8 juta setiap hari. Awal muncul pandemi bisa 1,7-2 juta per harinya.....kembali stabil penjualan di angka 1,5-1,8 juta per hari sampai sekarang ini....." (lk, 30 tahun)

Terjadinya penurunan penghasilan informan pada awal Covid-19 seperti yang dsampaikan oleh informan juga terlihat dalam rekapan hasil penjualan yang masih dimiliki informan. Berikut akan disajikan dalam grafik penghasilan informan sebelum pandemi (30 November 2019, 31 Desember 2019), awal pandemi (30 April 2020, 31 Mei 2020), dan saat penelitian ini dilakukan (27 Februari 2021, 31 Maret 2021). 


\section{Gambar 1. Hasil Penjualan Outlet Herbal dan Jamu Sehat Basamo Periode November-Desember} 2019, April-Mei 2020, dan Februari-Maret 2021

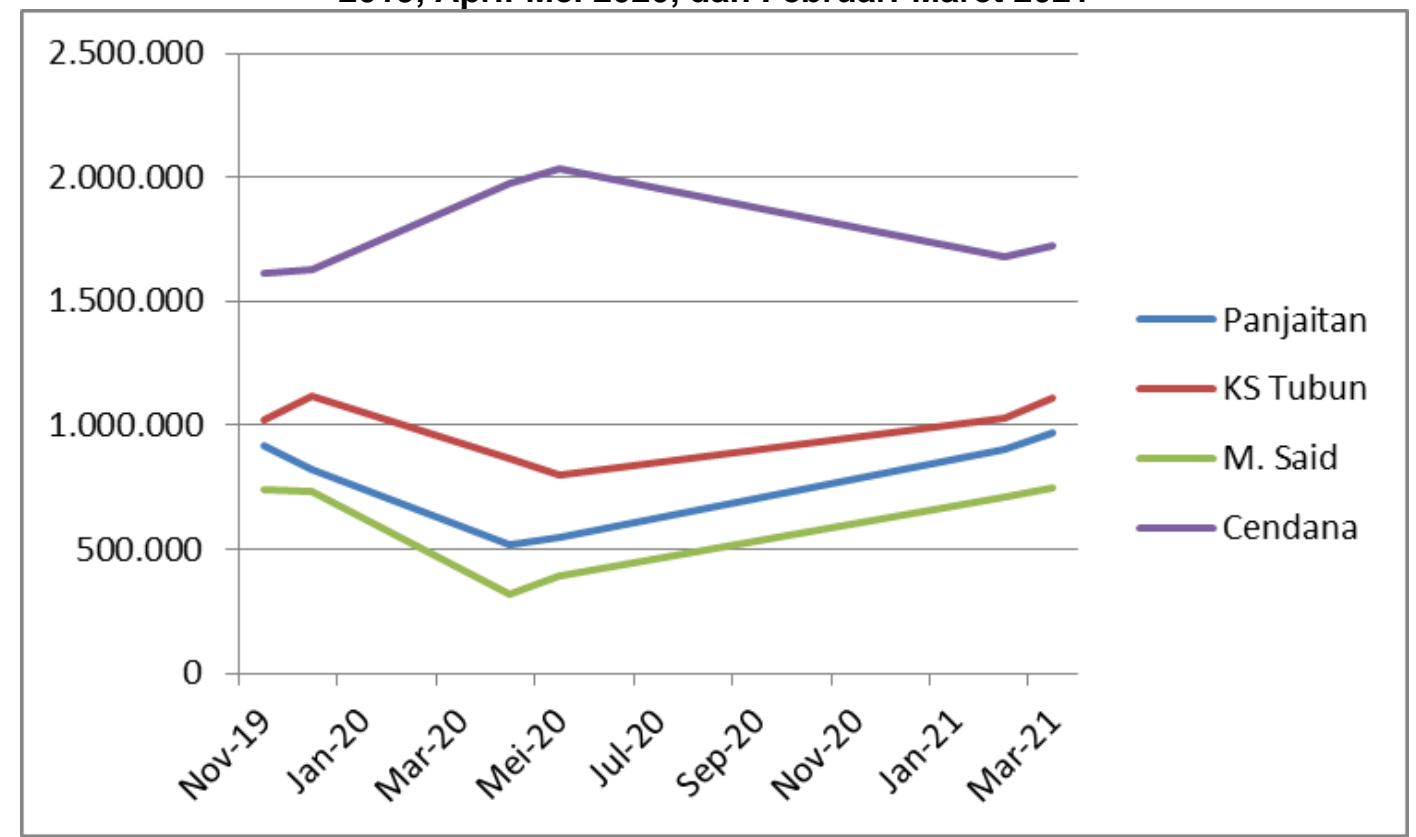

Sumber: Data Primer, 2021

Tampak pada Grafik 1 bahwa hasil penjualan herbal dan jamu pada 3 outlet Sehat Basamo mengalami penurunan penjualan pada awal Covid-19 tetapi terdapat 1 outlet Sehat Basamo yang mengalami peningkatan hasil penjualan. Namun, memasuki beberapa bulan berangsungnya Covid-19, semua outlet herbal dan jamu Sehat Basamo memperoleh hasil penjualan seperti sebelum Covid-19.

Penurunan penghasilan hasil penjualan yang dialami sebagian besar outlet herbal dan jamu Sehat Basamo di awal Covid-19 dapat disebabkan beberapa faktor antara lain dampak himbauan dan kebijakan pemerintah tentang pembatasan aktivitas di luar rumah sehingga sebagian masyarakat mengindahkan kebijakan tersebut, tetapi juga masih ditemukan masyarakat yang belum menerapkan protokol kesehatan Covid-19 berdasarkan hasil survey perilaku masyarakat di masa pandemi Covid-19 (BPS RI, 2020).

Penghasilan pemilik usaha herbal dan jamu Sehat Basamo juga dapat dipengaruhi lokasi tempat outlet penjualan berada. Lokasi suatu usaha mempengaruhi akses dan kemudahan dijangkau oleh kendaraan bermotor (Andrianto Beny, Zaini Oktori Kiswati, 2019). Lokasi semua outlet herbal dan jamu Sehat Basamo berada tepat di daerah padat lalu lintas kendaraan dan menjadi pilihan warga Kota Samarinda saat hendak menuju dan pulang dari tempat kerja sehingga menjadi alternatif pilihan bagi warga yang gemar mengkonsumsi herbal dan jamu.

Selain pemilihan lokasi, alokasi waktu yang digunakan untuk berjualan produk juga berpengaruh terhadap pendapatan pada UMKM (Sari, Meita Puspita,. Karmini, 2019). Terdapat salah satu outlet herbal dan jamu Sehat Basamo yang melakukan kegiatan penjualan sejak 
pagi hingga malam hari. Terbukti bahwa jumlah hasil penjualannya dalam sehari lebih tinggi dibandingkan tiga outlet lainnya. Penambahan jam operasional pada outlet herbal dan jamu Sehat Basamo di Jalan Cendana Kota Samarinda didukung oleh aktivitas ekonomi masyarakat dan lalu lintas kendaraan bermotor di jalan tersebut tetap ramai hingga larut malam dan bahkan 24 jam. Peluang pengelola outlet herbal dan jamu Sehat Basamo pada tiga lokasi lainnya dapat menambah alokasi waktu penjualan produk karena pengelola tidak memiliki kegiatan lain selain menjual herbal dan jamu.

Bertahannya usaha herbal dan jamu Sehat Basamo di Kota Samarinda meski di tengah badai pandemi Covid-19 tentunya tidak lepas dari strategi pemasaran yang diterapkan oleh pemiliknya. Informasi yang diperoleh dari informan bahwa mereka menerapkan strategi penjualan yang sama sebelum adanya pandemi Covid-19 yaitu konsisten dalam penyajian minuman terutama takaran dan kebersihan peralatan dan tempat usaha, tidak menaikkan harga minuman, sikap penjual yang ramah dan sopan, dan memastikan ketersediaan pasokan selalu terpenuhi. Selain itu, informan selalu meyakinkan pelanggan bahwa tempat usahanya menerapkan protokol kesehatan Covid-19. Sebagaimana hasil kutipan wawancara berikut ini :

“.....memperhatikan takaran saat pembuatan jamu.....harganya tidak dinaikkan biar seribu rupiah, selalu menjaga stok jualan dan yang penting adalah sikap ramah serta sopan terhadap pelanggan" (Ik, 30 tahun)

“....peralatan yang digunakan dan tempat juga harus bersih dan enak dipandang mata biar pelanggan tetap senang dan bisa ke sini lagi” (Vi, 22 tahun)

“.....karena ini pandemi jadi selalu meyakinkan pembeli bahwa tempat ini aman dari Covid" (Iv, 27 tahun)

Sikap konsisten yang selalu diperhatikan oleh informan dalam penyajian minuman terutama takaran dan kebersihannya merupakan salah satu strategi yang ditempuh pemilik usaha herbal dan jamu Sehat Basamo. Konsistensi takaran dalam membuat minuman herbal dan jamu akan mempengaruhi kualitas minuman yang disuguhkan kepada konsumen. Kualitas produk yang diperjualbelkan berpengaruh signifikan terhadap keputusan pembelian (Anjani, 2019).

Kemahiran informan dalam meracik dan menyajikan minuman herbal dan jamu agar tetap konsisten dapat dipengaruhi lamanya menggeluti usaha minuman tersebut. Usaha herbal dan jamu Sehat Basamo sudah cukup lama beroperasi di Kota Samarinda dan bahkan terdapat satu outlet yang sudah 10 tahun menjalani usahanya. Selain kecakapan informan dalam meracik minuman jamu juga sangat peduli terhadap kebersihan bahan baku, peralatan, dan tempat usahanya. Hal ini juga sampaikan oleh konsumen pada hasil kutipan wawancara berikut ini: 
“.....racikannya selalu mantap dan tidak pernah berubah.....sudah lama berlangganan jadi sudah bisa menilai takaran minumannya" (Ba, 33 tahun)

“.....kemasannya bersih, peralatannya juga tempatnya diperhatikan kebersihannya.....itulah makanya selalu kemari" (Su, 52 tahun)

Selain konsisten dalam penyajian dan kebersihan yang tetap diperhatikan, harga yang dipatok oleh penjual herbal dan jamu Sehat Basamo merupakan harga jual pada umumnya dan bahkan di bawah harga pasaran sehingga penikmat minuman herbal dan jamu merasa tidak keberatan untuk kembali berbelanja. Strategi penjualan usaha herbal dan jamu SB yang tidak menaikkan harga terutama pada masa pandemi Covid-19 pula telah dipahami dan dipraktikkannya sehingga minuman herbal dan jamu mereka tetap diburu oleh pelanggan.

Menurut salah seorang pembeli mengatakan bahwa justru merasa kaget dengan harga yang ditawarkan oleh outlet herbal dan jamu Sehat Basamo di bawah harga rata-rata penjual produk serupa di tempat lainnya. Pembeli lainnya juga menyampaikan bahwa sering memperoleh potongan harga dari pemilik outlet herbal dan jamu Sehat Basamo. Sebagaimana hasil kutipan wawancara berikut ini :

“....saya kaget kok harganya jauh di bawah harga jual di warung lain padahal produknya sama" (Su, 52 tahun)

“.....sering dapat potongan harga dan bahkan kalau kurang uang belanja, mas penjualnya bilang nanti saja bayarnya” (Od, 32 tahun)

Harga suatu produk yang diperjualbelikan dapat mempengaruhi keputusan calon pembeli dalam berbelanja. Terbukti bahwa beberapa pelanggan yang berkunjung ke outlet herbal dan jamu Sehat Basamo merupakan pelanggan sebelumnya di outlet lain (bukan milik Sehat Basamo) dan mereka mengeluhkan adanya kenaikan harga yang kurang wajar sejak pandemi Covid-19. Persepsi pembeli mengenai harga suatu produk berpengaruh terhadap persepsi peningkatan penjualan (Segati, 2018). Selain itu, harga juga berpengaruh positif dan signifikan terhadap kepuasan konsumen (Ofela, 2016). Strategi yang dilakukan di outlet herbal dan jamu Sehat Basamo dengan tidak menaikkan harga herbal dan jamu dapat dipertahankan dan ditingkatkan, dan jika pengelola menerapkan harga baru produknya, maka sebaiknya pengelola memberikan penjelasan dan pemahaman kepada pelanggan.

Selain ketetapan harga yang relatif lebih murah dibanding tempat lainnya yang menjual produk serupa, pihak penjual herbal dan jamu Sehat Basamo juga senantiasa menjaga ketersediaan pasokan produknya agar selalu memenuhi permintaan pelanggan. Hal tersebut disampaikan juga oleh pelanggan herbal dan jamu Sehat Basamo seperti hasil kutipan wawancara berikut :

“.....selalu tersedia apa yang dimau di sini....” (Em, 35 tahun) 
“.....kalau pas lagi kosong, pasti dikabari kalau stoknya sudah ada. Kalau malam ini tidak ada, palingan besok dikabari bahwa barangnya sudah ada” (Od, 32 tahun)

Outlet herbal dan jamu yang berada di bawah naungan Sehat Basamo hampir setiap hari melakukan komunikasi dan bahkan pertemuan tidak secara formal membahas ketersediaan stok di setiap outlet. Jika terdapat salah satu outlet yang lagi kekosongan produk tertentu, outlet lainnya yang memiliki cukup produk akan memberikan ke outlet yang kekurangan stok herbal dan jamu tersebut sehingga ketersediaan pasokan di semua outlet herbal dan jamu Sehat Basamo selalu tersedia. Ketersediaan pasokan dapat mempengaruhi keputusan seseorang dalam pembelian produk. Produk yang tidak tersedia secara lengkap atau hanya tersedia sebagian produk berpengaruh terhadap keputusan pembelian (Dwinito, 2020).

Penjual herbal dan jamu Sehat Basamo juga menerapkan secara konsisten pelayanan terbaiknya kepada pelanggan. Keputusan seseorang untuk melakukan pembelian sesuatu produk dipengaruhi kualitas pelayanan (Sholihat, 2019). Kualitas pelayanan berpengaruh positif dan signifikan terhadap kepuasan konsumen (Ofela, 2016). Sikap ramah dan sopan selalu ditampakkan oleh penjual herbal dan jamu Sehat Basamo saat melayani pelanggan. Sikap positif yang ditunjukkan informan tersebut dapat memberikan kepuasan terhadap para pelanggannya sehingga pelanggan Sehat Basamo tetap setia hingga kini. Hal tersebut sesuai kutipan hasil wawancara kepada pelanggan herbal dan jamu SB sebagai berikut :

“.....saya pelanggan bisa dikata setia karena minum di sini sejak mulai jualan sampai sekarang jadi yah sekitar 10 tahun.....penjualnya ramah dan juga sopan jadi itu sebabnya betah belanja di sini" (Su, 52 tahun)

“.....penjualnya selalu tersenyum dan ramah, pokoknya baiklah jadi kita sebagai pembeli juga puas dengan pelayanannya...." (Em, 35 tahun)

Usaha herbal dan jamu Sehat Basamo selama Covid-19 tetap beroperasi seperti biasanya tetapi penerapan protokol kesehatan yang ditunjukkan oleh penjualnya dan bahkan fasilitas yang disediakan telah memenuhi himbauan pemerintah tentang protokol kesehatan yaitu dengan memakai masker, menjaga jarak, mencuci tangan atau cairan hand sanitizer (Kemenkes RI, 2020). Informan selalu meyakinkan kepada pelanggan bahwa tempat usaha mereka menerapkan protokol kesehatan. Perilaku kepatuhan protokol kesehatan yang ditunjukkan informan dapat mempengaruhi perilaku pelanggan untuk mengikutinya.

Di tengah pandemi Covid-19, masyarakat mencari berbagai cara untuk mencegah agar mereka tidak mudah terserang virus dan gangguan penyakit lainnya. Selain alasan menjaga kekebalan tubuh agar tidak mudah sakit, pengunjung herbal dan jamu Sehat Basamo mengatakan bahwa mereka rutin meminum jamu karena sudah menjadi kebutuhan setelah bekerja seharian. Informasi tersebut dapat dilihat pada kutipan hasil wawancara berikut : 
“.....agar tidak mudah sakit, apalagi pandemi sekarang ini jadi seharusnya pintar menjaga tubuh biar tetap sehat" (Od, 32 tahun)

“.....saya bekerja seharian dan rasanya badan terasa capek kalau tidak minum jamu.....bisa dibilang minum jamu ini kebutuhan sudah" (Ba, 33 tahun)

Peluang permintaan dari masyarakat sebagai konsumen yang cukup tinggi dalam konsumsi minuman herbal dan jamu selama pandemi Covid-19 merupakan salah satu faktor pendukung sehingga usaha seperti ini mampu bertahan di antara banyaknya usaha lain yang mengalami kebangkrutan. Pemilik usaha herbal dan jamu dapat memanfaatkan peluang ini sebagai kekuatan mereka untuk mempertahankan usahanya dan tetap memperoleh keuntungan di tengah badai pandemi Covid-19. Masyarakat konsumen herbal dan jamu berupaya mempertahankan kondisi kesehatan dan stamina mereka selama pandemi, sehingga memilih alternatif minuman jamu yang diyakini sebagai minuman kesehatan dan meningkatkan daya tahan tubuh.

Pemilik usaha herbal dan jamu Sehat Basamo juga menyadari bahwa era teknologi dan informasi saat ini dapat membantu pelaku usaha dalam meningkatkan penghasilan karena mampu menjangkau calon pembeli yang bertempat tinggal jauh dari tempat usahanya. Akan tetapi, hingga penelitian ini dilakukan informan mengatakan bahwa belum menemukan formulasi strategi yang sesuai dengan produk yang dijualnya karena selama beroperasi pelanggannya datang langsung berbelanja dan minum di outletnya. Informan juga telah memberikan nomor telepon mereka kepada pelanggannya dan biasanya pelanggan menghubungi informan saat dalam perjalanan menuju outlet herbal dan jamu Sehat Basamo.

Berdasarkan informasi yang diperoleh juga dari informan bahwa pernah beberapa kali melayani pesanan pelanggannya melalui perantara aplikasi penyedia jasa pengantar makanan dan minuman. Pelanggan informan tersebut memesan minuman herbal dan jamu Sehat Basamo melalui penggunaan layanan atau fitur konsumen (Kartika, 2020) berupa layanan GoShop bagi pengguna aplikasi Go-Shop (Mutma'innah, 2018). Meskipun pemesanan minuman herbal dan jamu di outlet Sehat Basamo melalui aplikasi online masih jarang terjadi, akan tetapi hal ini dapat dijadikan sebagai suatu peluang strategi untuk memperluas jangkauan pelanggan yang dapat mempengaruhi tambahan hasil penjualan produk.

Adanya keterbukaan penerimaan teknologi dan informasi pada pemilik usaha herbal dan jamu Sehat Basamo dapat menjadi salah satu faktor pendukung dalam pemanfaatan aplikasi jasa penjualan online yang sudah tersedia di Kota Samarinda. Usaha herbal dan jamu Sehat Basamo di Kota Samarinda sejak berdirinya hingga saat ini masih melakukan transaksi penjualan secara langsung kepada pelanggan, akan tetapi seiring perkembangan teknologi dan informasi serta untuk memaksimalkan pelayanan khususnya kepada pelanggan yang berdomisili jauh dari outlet Sehat Basamo, maka strategi penjualan melalui aplikasi jasa 
penjualan minuman herbal dan jamu secara online bukanlah sesuatu hal yang negatif bagi keberlangsungan usaha khususnya di masa pandemi Covid-19.

Selain itu, menurut informasi yang diperoleh dan dokumen pencatatan keuangan yang dimiliki oleh outlet herbal dan jamu Sehat Basamo masih dilakukan secara manual pada buku catatan. Akibatnya, banyak laporan pencatatan keuangan outlet yang tidak tersedia karena rusak dan telah hilang. Pengelolaan pencatatan laporan keuangan yang diterapkan oleh outlet herbal dan jamu Sehat Basamo saat ini dinilai kurang efektif dan efisien. Oleh karena itu, pemanfaatan teknologi informasi juga dapat diterapkan dalam pencatatan atau pembukuan keuangan secara digital (digital accounting) dalam pengelolaan keuangan usahanya.

Para pemilik usaha akan memperoleh sejumlah keuntungan jika melakukan laporan pencatatan keuangan secara digital antara lain memudahkan dalam memonitor dan mengevaluasi semua transaksi yang terjadi dalam menjalankan usaha. Pelaku UMKM tidak perlu repot membuat laporan keuangan secara manual (Indra, 2020), sehingga akan membuat pekerjaan lebih efisien dan efektif terutama dalam melakukan pencatatan transaksi keuangan yang dilakukan saat operasional penjualan herbal dan jamu. Penerapan sistem digital saat ini telah tersedia banyak dalam mengelola akuntansi keuangan dengan berbagai software aplikasi yang sangat mudah digunakan oleh pengelola usaha yang disesuaikan kemampuan dan kebutuhan pemilik usaha.

Pandemi Covid-19 yang belum diketahui kira-kira kapan berakhirnya dan hingga kini tidak satu pun hasil penelitian dan pakar yang mampu memastikan kapan pandemi Covid-19 berhasil dihentikan (Sultan, 2021). Berdasarkan kondisi tersebut sehingga diperlukan ilmu dan seni dari pelaku usaha agar mampu mempertahakan usahanya khususnya di tengah badai pandemi Covid-19 dan tetap berupaya memaksimalkan peluang memperoleh keuntungan dari usaha yang dijalankannya. Badai pandemi Covid-19 ini bukanlah akhir dari segalanya bagi pelaku usaha, akan tetapi kejadian pandemi yang masih berlangsung hingga saat ini dapat menjadi motivasi agar lebih inovatif dalam menciptakan strategi pengembangan usaha di masa pasca pandemi Covid-19.

\section{Kesimpulan, Keterbatasan, dan Saran}

\subsection{Kesimpulan}

Pemilik usaha herbal dan jamu Sehat Basamo di Kota Samarinda dan pelanggan yang berkunjung di outlet Sehat Basamo menunjukkan kepatuhan dalam menerapkan protokol kesehatan Covid-19. Selain kepatuhan menerapkan protokol kesehatan, pelaku usaha herbal dan jamu Sehat Basamo juga terbukti masih mampu bertahan dan bahkan tetap meraup keuntungan dari hasil penjualan produknya di tengah badai pandemi Covid19. Kemampuan bertahan dan keberhasilannya memperoleh keuntungan di tengah badai 
pandemi tersebut dicapai dengan menerapkan strategi yang sama seperti sebelum Covid19 yakni sikap konsisten dalam penyajian produk, tidak menaikkan harga produk, keramahan dan kesopanan penjual serta menjamin ketersediaan produk. Aktivitas jual-beli di outlet herbal dan jamu Sehat Basamo lebih banyak dilakukan secara langsung dengan pembeli dan pengelolaan akuntansi keuangannya masih secara manual.

5.2. Keterbatasan

Keterbatasan yang dialami peneliti saat penelitian ini dilaksanakan antara lain keterbatasan rekaman arsip penjualan produk di semua outlet Sehat Basamo karena masih dicatat secara manual.

5.3. Saran

Pemilik usaha herbal dan jamu Sehat Basamo Kota Samarinda dapat memanfaatkan teknologi dan informasi seperti pengelolaan akuntansi keuangan hasil penjualan produk berbasis digital (digital accounting) yang telah tersedia dalam berbagai software aplikasi. Selain itu, pemanfaatan teknologi dan informasi dapat membuka peluang kerjasama dengan pihak penyedia jasa penjualan online yang sudah tersedia di Kota Samarinda. Selain itu, diperlukan studi lebih lanjut tentang implementasi dan sekaligus evaluasi pemanfaatan aplikasi penjualan online terhadap peningkatan hasil penjualan produk usaha herbal dan jamu Sehat Basamo.

\section{Daftar Pustaka}

Abidin, Z., Zendo Azhari, T., Naufal Esfandiar, W., Nuryaningrum, N., Farah Dhilah Syifana, A., \& Cahyaningrum, I. (2020). Pemanfaatan Media Sosial dalam Pemasaran Produk UMKM di Kelurahan Sidokumpul, Kabupaten Gresik. Jurnal IImu Komunikasi, 10(1), 17-31. https://doi.org/10.15642/jik.2020.10.1.17-31

Agustino, L. (2020). Analisis Kebijakan Penanganan Wabah Covid-19: Pengalaman Indonesia Analysis Of Covid-19 Outbreak Handling Policy: The Experience Of Indonesia. Junal Borneo Administrator, 16(2), 253-270.

Alfin, A. (2021). Analisis Strategi UMKM Dalam Menghadapi Krisis di Era Pandemi COVID-19. Jurnal Inovasi Penelitian, 1(10), 1-208.

Amri, A. (2020). Dampak Covid-19 Terhadap UMKM di Indonesia. Jurnal Brand, 2(1), 123-130. https://www.academia.edu/42672824/Dampak_Covid-19_Terhadap_UMKM_di_Indonesia

Andriani, A. J. (2021). Pengaruh Packaging, Promosi Melalui Media Sosial dan Variasi Produk Terhadap Keputusan Pembelian Konsumen (Studi Kasus Niten Jamu Semarang). Jurnal Visi Manajemen, 6(1), 906-920.

Andrianto Beny, Zaini Oktori Kiswati, R. S. H. (2019). Lokasi Salah Satu Faktor yang Mempengaruhi Keputusan Pembelian Produk Pada Torii Resto. Manajemen, Fakultas 
Ekonomi Universitas Pakuan, 1-11.

Anjani, W. P. (2019). Pengaruh Kualitas Produk Dan Iklan Terhadap Keputusan Pembelian Coca-Cola Melalui Brand Image Sebagai Variabel Intervening (Studi Pada Konsumen Minuman Ringan Bersoda Merek Coca-Cola Di Kota Semarang). Pengaruh Kualitas Produk Dan Iklan Terhadap Keputusan Pembelian Coca-Cola Melalui Brand Image Sebagai Variabel Intervening (Studi Pada Konsumen Minuman Ringan Bersoda Merek Coca-Cola Di Kota Semarang), 8(1), 26-34.

Arianto, B. (2020). Pengembangan UMKM Digital di Masa Pandemi Covid-19. ATRABIS: Jurnal Administrasi Bisnis, 6(2), 233-247.

Awali, H. (2020). Urgensi Pemanfaatan E-Marketing Pada Keberlangsungan Umkm Di Kota Pekalongan Di Tengah Dampak Covid-19. BALANCA : Jurnal Ekonomi Dan Bisnis Islam, 2(1), 1-14. https://doi.org/10.35905/balanca.v2i1.1342

Azizuddin, I. (2021). Jamu tradisional peningkat imunitas di masa pandemi. Journal of Research on Community Engagement, 2(2), 38-42. https://doi.org/10.18860/jrce.v2i2.11962

BNPB. (2020). Transkrip Keterangan Presiden Soal Pembatasan Sosial Berskala Besar atau PSBB. Bnpb.Go.ld.

BPS RI. (2020). Hasil Survei Perilaku Masyarakat Di Masa Pandemi Covid-19 (7-14 September 2020). In Perilaku Masyarakat di Masa Pandemi Covid-19 BPS RI.

Dewati, R., \& Saputro, W. A. (2020). Persepsi Konsumen Terhadap Pembelian Produk Herbal Di Kabupaten Sukoharjo. AGRISAINTIFIKA: Jurnal IImu-IImu Pertanian, 4(2), 144. https://doi.org/10.32585/ags.v4i2.889

Drajat AR, et al. (2020). Pengembangan Usaha Jamu Herbal Untuk Meningkatkan Imunitas Tubuh Dalam Menghadapi Pandemu Covid-19. Civitas Ministerium, 4(01), 61-68.

Dwiastanti, Anis, Mustapa, G. (2020). Pengaruh Karakteristik Wirausaha, Lingkungan Eksternal dan Strategi Bertahan UMKM Dalam Menjaga Keberlangsungan Usaha di Musim Pandemi COVID 19. Business and Accounting Education Journal, 1(3), 229-237.

Dwinito, R. (2020). Strategi pemasaran kopi janji jiwa terhadap keputusan pembelian di gerai pondok ungu permai bekasi 1. In repository.stei.ac.id/id/eprint/1639.

Hardilawati, W. laura. (2020). Strategi Bertahan UMKM di Tengah Pandemi Covid-19. Jurnal Akuntansi Dan Ekonomika, 10(1), 89-98. https://doi.org/10.37859/jae.v10i1.1934

Hariyanti, M. (2015). Analisis Data Kualitatif Miles dan Hubermen. Kompasiana.

Indra, Y. A. (2020). Penerapan Sebelum dan Sesudah Sistem Informasi Akuntansi Syariah dengan Menggunakan Aplikasi Software Accounting Dalam Penyusunan Laporan Keuangan Bagi UMKM. Al-Intaj; Jurnal Ekonomi Dan Perbankan Syariah.

Ingsih, I. S., Winaktu, G., Teknik, F., Malang, U. I., Candirenggo, K., \& Singosari, K. (2020). Pembuatan Jamu Tradisional Kunyit Asam Sebagai Minuman Peningkat Daya Imunitas 
Tubuh Pada Masa Pandemi COVID-19. 328-339.

Jati, W. (2020). Merajut Optimisme di tengah Covid 19. http://eprints.unpam.ac.id/8680/2/Bunga Rampai 3 Merajut Optimisme di tengah Covid 19 Final.pdf

Kalimantan Timur, P. P. (2020). Surat Edaran Gubernur Kalimantan Timur tentang Tindak Lanjut Terkait Pencegahan Penyebaran Covid-19 di Lingkungan Pemerintah Provinsi Kalimantan Timur.

Kartika, N. E. (2020). Fitur Aplikasi Gojek Favorit Konsumen Pada Saat Pandemi COVID-19 Di Kota Bandung Gojek Application Features Favorite for Consumers during the COVID-19 Pandemic in Bandung City yang menjadi minat masyarakat adalah diterima oleh khalayak dan banyaknya menin. Jurnal IImu Komunikasi, 9(2), 1680-1695.

Kemenkes RI. (2020). Pedoman Perubahan Perilaku. Pedoman Perubahan Perilaku Penanganan Covid-19.

Khusnul Zauhani. (2020). Infeksi Covid-19 Dan Sistem Imun: Peran Pengobatan Herbal Berbasis Produk Alam Berkhasiat Covid-19 Infection and the Immune System : the Role of Herbal. JIP - Jurnal IImiah Pamenang, 2(2), 26-31.

Kusmarni, Y. (1989). STUDI KASUS (John W . Creswell) Oleh Yani Kusmarni. 1-12.

Mutma'innah, S. (2018). Tanggung Jawab Hukum Para Pihak Pada Transaksi Jual Beli Melalui Aplikasi G-Shop. https://repository.unej.ac.id/handle/123456789/88696

Natasya, V., \& Hardiningsih, P. (2021). Kebijakan Pemerintah Sebagai Solusi Meningkatkan Pengembangan UMKM di Masa Pandemi. Ekonomis: Journal of Economics and Business, 5(1), 141. https://doi.org/10.33087/ekonomis.v5i1.317

Ofela, H. (2016). Pengaruh harga, kualitas produk dan kualitas pelayanan terhadap kepuasan konsumen kebab kingabi. Jurnal IImu Dan Riset Manajemen, 5(1), 1-15.

Prakoso, F. A. (2020). Dampak Coronavirus Disease (Covid-19) Terhadap Industri Food \& Beverages. Jurnal Manajemen Bisnis, 33(2), 1-6.

Priangani, A. (2013). Memperkuat Manajemen Pemasaran Dalam Konteks Persaingan Global. Jurnal Kebangsaan, 2(4), 1-9.

Putra RP, I. S. (2020). Inovasi Kemasan dan Pemasaran Digital Produk UMKM Tisya Herbal di Desa Mulyoarjo. CIASTECH 2020 "Peranan Strategis Teknologi Dalam Kehidupan Di Era New Normal, Ciastech, 1237-1244.

Rini Eka Sari, Novi Yanita, S. N. (2020). Strategi Usaha Biro Perjalanan Wisata Sumatera Barat Dalam Menghadapi Krisis Pandemi Covid-19. JSHP: Jurnal Sosial Humaniora Dan Pendidikan, 5(1), 55-62. https://doi.org/10.32487/jshp.v5i1.945

Rosmadi, M. L. N. (2021). Penerapan Strategi Bisnis di Masa Pandemi Covid-19. Jurnal IKRAITH Ekonomika, 4(1), 122-127.

Samarinda, P. K. (2021). Surat Edaran Walikota Samarinda Tentang Penegakan Protokol 
Kesehatan Pada Kegiatan di Malam Hari.

Sari, Meita Puspita,. Karmini, N. L. (2019). Beberapa Faktor yang Mempengaruhi Pendapatan Keluarga Pada UMKM di Kecamatan Kuta Utara. E-Jurnal Ekonomi Dan Bisnis Universitas Udayana, 10, 1161-1192.

Segati, A. (2018). Pengaruh Persepsi Sertifikasi Halal, Kualitas Produk, Dan Harga Terhadap Persepsi Peningkatan Penjualan. JEBI (Jurnal Ekonomi Dan Bisnis Islam), 3(2), 159. https://doi.org/10.15548/jebi.v3i2.175

Shofiana, A. (2020). IMPLEMENTASI PROGRAM AFILIASI BERBASIS VIRTUAL TEAM DALAM UMKM SEBAGAI UPAYA PENINGKATAN PEREKONOMIAN PADA MASA PANDEMI COVID-19 (Implementation of Virtual Team-Based Affiliation Programs in MSMEs as Efforts for Increasing the Economy in the COVID-19 Pand. SSRN Electronic Journal. https://doi.org/10.2139/ssrn.3590822

Sholihat, A. (2019). Pengaruh Promosi Penjualan Dan Kualitas Pelayanan Terhadap Keputusan Pembelian Di Krema Koffie. Journal of Chemical Information and Modeling, 53(9), 16891699.

Soetjipto, N. (2020). Ketahanan UMKM Jawa Timur Melintasi Pandemi COVID-19. In K-Media.

Sugiri, D. (2020). Menyelamatkan Usaha Mikro, Kecil dan Menengah dari Dampak Pandemi Covid-19. Fokus Bisnis: Media Pengkajian Manajemen Dan Akuntansi, 19(1), 76-86. https://doi.org/10.32639/fokusbisnis.v19i1.575

Sultan, M. (2021). Mendorong Keberhasilan Vaksinasi COVID-19. Detik.Com, 5(4), 1-2. https://news.detik.com/kolom/d-5520578/mendorong-keberhasilan-vaksinasi-covid-19

Sumarni, Y. (2020). Pandemi Covid-19: Tantangan Ekonomi Dan Bisnis. Al Intaj: Jurnal Ekonomi Dan Perbankan Syariah, 6(2), 46-58.

Sutana, A. A. P. D. (2020). Perilaku Konsumsi Jamu Tradisional Di Tengah Pandemi Covid-19. Yayasan Kiat Menulis.

Syaiful, F. F. (2020). Manajemen Entrepreneurship Education melalui pemasaran di tengah Pandemi covid-19: Studi kasus usaha minuman Kamsia Boba di Kabupaten Bangkalan. Jurnal Edukasi Nonformal, 2634(April 2020), 336-342.

Thaha, A. F. (2020). Dampak Covid-19 Terhadap UMKM Di Indonesia [The Impact of Covid-19 on MSMEs in Indonesia]. Brand, 2(1), 148-153.

Yasir, M., Muharrami, L. K., \& Wasonowati, C. (2020). Pengembangan Kapasitas Pemasaran Jamu Naturna Melalui Inovasi Teknologi Berbasis Website. BAKTIMAS: Jurnal Pengabdian Pada Masyarakat Universitas Serambi Mekkah Banda Aceh, 2(4), 173-180. 